\title{
Human Rights and State Security
}




\section{PENNSYLVANIA STUDIES IN HUMAN RIGHTS}

Bert B. Lockwood, Jr., Series Editor

A complete list of books in the series is available from the publisher. 


\title{
Human Rights and
}

\section{State Security}

\author{
Indonesia \\ and the \\ Philippines
}

\author{
Anja Jetschke
}

\section{PENN}


Copyright (c) 2011 University of Pennsylvania Press

All rights reserved. Except for brief quotations used for purposes of review or scholarly citation, none of this book may be reproduced in any form by any means without written permission from the publisher.

\author{
Published by \\ University of Pennsylvania Press \\ Philadelphia, Pennsylvania 19104-4112 \\ www.upenn.edu/pennpress \\ Printed in the United States of America \\ on acid-free paper
}

$\begin{array}{llllllllll}10 & 9 & 8 & 7 & 6 & 5 & 4 & 3 & 2 & 1\end{array}$

Library of Congress Cataloging-in-Publication Data

Jetschke, Anja.

Human rights and state security : Indonesia and the Philippines / Anja Jetschke.

p. cm. - (Pennsylvania studies in human rights)

Includes bibliographical references and index.

ISBN 978-0-8122-4301-7 (hardcover : alk. paper)

1. Human rights-Indonesia. 2. Human rights-Philippines. 3. Human rights advocacy-Indonesia. 4. Human rights advocacy-Philippines. 5. International and municipal law-Indonesia. 6. International and municipal law-Philippines. I. Title. II. Series: Pennsylvania studies in human rights JC599.I5J48 2011

323.09598-dc22 
For Quirin and Jan 
This page intentionally left blank 